\title{
Material flow analysis of the forest-wood supply chain: a consequential approach for log export policies in France
}

\author{
Jonathan Lenglet ${ }^{\mathrm{a}, *}$, Jean-Yves Courtonne ${ }^{\mathrm{b}, \mathrm{c}, \mathrm{d}}$, Sylvain Caurla ${ }^{\mathrm{e}}$ \\ ${ }^{a}$ AgroParisTech, France \\ ${ }^{b}$ STEEP team, INRIA Grenoble - Rhône-Alpes, Montbonnot, France \\ ${ }^{c}$ Université Grenoble Alpes, France \\ ${ }^{d}$ Artelia Eau et Environnement, Echirolles, France \\ ${ }^{e}$ UMR INRA - AgroParisTech, Laboratoire d'Économie Forestière, 54042 Nancy Cedex, France
}

\begin{abstract}
Part of the French timber transformation industry suffers from difficulties to adapt to recent changes on global markets. This translates into net exports of raw wood and imports of transformed products, detrimental to both the trade balance and the local creation of wealth. At the same time, no consistent and homogeneous accounts for wood product production and consumption exist at this time. This article first aims at objectifying this situation by undertaking the first material flow analysis of the French forestwood supply chain. We then evaluate the potential consequences of various scenarios of raw wood exports reduction policies, namely subsidies for consumption or transformation and taxation of exports, on both economic outcomes for the different actors and material flows. We thus provide an example of coupling material flow analysis with economic modeling in an attempt to move from the diagnostic phase to the assessment of possible actions within a decision-making perspective.
\end{abstract}

\footnotetext{
${ }^{*}$ Corresponding author

Email addresses: jonathan. lenglet@agroparistech.fr (Jonathan Lenglet), jean-yves.courtonne@inria.fr (Jean-Yves Courtonne), sylvain. caurla@inra.fr (Sylvain Caurla)
} 


\section{Introduction}

In France, the forest cover is expanding rapidly. In 2016, forests and woodlands cover more than one third of the national territory, making France the fourth most forested country in Europe. The current volume of wood in forest stands is estimated to be 2.6 billions cubic meter and represents a significant ressource potential for forests and timber industries (IGN, 2016). Yet, the economic balance-sheet remains relatively modest and the sector still presents an important trade-balance deficit. Relocating sawmill activities on the national territory is more and more presented as a solution to ensure the provision of sawnwood products while reducing trade deficit (Alexandre, 2017). However this raises questions such as which sawmill industries should be relocated, to what extent and what would be the consequences over the rest of the wood sector, in terms of competition, trade-offs and/or synergies.

With this in mind, we strongly believe that any recommendation to relocate sawmill activities, either by stimulating private investments or by implementing public policies, should rely on a comprehensive pattern of wood harvests, flows and uses. The primary goal of this paper is therefore to assess wood product flows in a comprehensive manner, following their pathway from the time the wood is harvested in the forest, along the transformation process, and ending with the consumption of transformed products. We particularly focus on outgoing and ingoing flows. This endeavor typically falls in the field of Material Flow Analysis (MFA), that is, a systematic assessment of the flows and stocks of materials within a system defined in space and time (Brunner and Rechberger, 2003).

Recent developments in the industrial ecology (IE) research field emphasize the relevance of MFA methods to obtain a precise understanding of systems and sub-systems functioning. The IE approach aims to provide necessary knowledge to support environmental, economic and social progress in an interactive system of processes and industries (for a detailed history of IE, see Erkman (1997)). Even though the main objective is to enhance sectors eco-efficiency (i.e. wastes and emissions reduction, energy and raw material use optimization), benefits can be broader (Burström and Korhonen, 2001). As stressed by Ehrenfled (2004) and Bringezu and Moriguche (2002), MFA is now recognized as a scientific support tool for decision makers, notably in the field of environmetal policy. However, within this context, MFA can also contribute to economic and societal development by shifting from a linear to a circular approach, leading to an overall 'win-win-win' outcome (Gibbs et al., 2005). The forest-wood sector offers a good example this multifunctionality. It provides employment, partly non-relocatable, recreation and participate in resource management and development of rural areas.

To our knowledge, so far, only Bais et al. (2015) have extensively quantified wood flows at the global scale, suggesting that there are still considerable uncertainties about the extraction of wood at the global level and especially of woodfuels. Other identified wood flow studies have focused on regional levels (Binder et al. 2004; Mantau, 2015), national levels (Hekkert et al., 2000) for the Netherlands, Hashimoto and Moriguchi (2004) for Japan, Piskur and Krajnc (2007) for Slovenia, Knaggs and O'Driscoll (2008) for Ireland, Cheng et al. (2010) for China, METLA (2011) for Finland, Weimar (2009) for Germany, Parobek et al. (2014) for Slovakia), as well as on the European Union as a whole (Mantau. 2012). Such studies are currently lacking in France where no consistent and homogeneous accounts for wood product production and consumption exist at this time. Forest management and wood extraction are generally treated separately from wood transformation (which is itself organized into many different federations). Different units are used in official reports (cubic meters of roundwood, cubic meters of product, metric tons, number of units produced) making it difficult to cross-check the data. In addition, large uncertainties prevail in some existing databases, especially regarding woodfuels that are known to be largely under-reported in official statistics (Chevallier et al. 2014). This article is a first attempt to fill this gap and provide a comprehensive view of the flows in the French forest-wood supply chain. One limitation of MFA that is usually pointed out concerns the lack or the availability of data and its high degree of uncertainty (Schwab et al., 2016, Patricio et al. 
2015). To tackle this issue, we propose to rely on the MFA framework depicted in Courtonne et al. (2015), which uses the wood fiber equivalent (presented in Section 2) as a basic accounting unit.

The second goal of this paper is to assess the impacts of the relocation of sawmill activities on other forest sectors such as the fuelwood and pulp sectors, as well as on the economic outcomes for the sector agents. To address this issue, we couple the MFA with a partial equilibrium forest sector model, the French Forest Sector Model (Lobianco et al., 2015, Caurla et al., 2013b a; Lecocq et al., 2011) and we explore the economic consequences of three policy options that reduce roundwood export.

By combining a MFA and a partial equilibrium framework, this paper makes it possible to bridge the gap between the diagnosis phase and the recommendation phase for policy makers through a multi-scenarios analysis. Indeed, as Binder (2007) and Binder et al. (2009) recall, the impact of MFA on policy making is not clear since most studies stop at the diagnostic phase. We propose to go beyond the diagnosis in order to provide policy relevant information by using a partial equilibrium model that projects the evolution of the forest sector at the same scale and for the same products as those described in the MFA. Compared to Bouman et al. (2000) who focused on how different approaches (LCA, MFA and partial equilibrium model) independently contribute to elucidating a research question, we undertake the coupling of MFA with economic modeling. Note that in the title, we refer to this as a consequential approach in reference to consequential Life Cycle Assessment (LCA) that, contrary to attributional LCA, models economic links between processes and is therefore able to account for the indirect effects of a change. In practice, this generally translates into nonlinearities, because of the existence of thresholds or scaling effects.

The article is organized as follows. The first section is dedicated to the presentation of the data sources, hypotheses and methodologies used, both for the MFA and the parts dealing with economic prospectives. Results are presented and discussed in a second section before concluding on the main findings of the study and on future research perspectives within the context of a transition to sustainability.

\section{Materials and methods}

\subsection{Material Flow Analysis (MFA)}

\subsubsection{Boundaries of the study}

We focus on the upstream part of the forest-wood supply chain, which is the most relevant to our research questions. Firstly, this makes it possible to analyze to what extent the country is exporting raw products and importing products of first transformation. Secondly, it provides information on log outlets, a key question, for example, being: is there a reason to worry that firewood is cannibalizing log resources at the expense of the lumber industry? As a consequence, the model implemented does not aim to represent some second or third transformation industries such as the furniture industry. More precisely, our MFA covers all log products (distinguishing hardwood from softwood), wooden pallets, sawnwood, veneer, plywood and wood panels, as well as energy wood, sawmill residues, pulp and paper products and niche products such as wood staves. A full list of the products considered is presented in Figure 6 in the supplementary material. The geographic boundary of the study is metropolitan France.

\subsubsection{Reference unit}

To make the MFA consistent we need to define a homogeneous unit for the entire wood chain. This is all the more important given that wood products data are reported in various units. Bösch et al. (2015) note that when quantities of wooden products are converted into the same unit in order to compare them, the cubic meter of roundwood equivalent is often used. It is defined as the volume of roundwood necessary to make 
one unit of processed product. However, we share their opinion that it cannot be directly used in MFA studies since it leads to double-counting of by-products such as sawmill residues. Using cubic meters or tonnes also raises consistency issues since other constitutive materials such as adhesives in panels or additives in paper products are then considered to be wood, whereas, volume changes due to drying would not be accounted for.

We therefore use the wood fiber equivalent as the reference unit. The unit is used in comparable studies in other european countries (Mantau, 2012 ; Bosch, 2015 ; Weimar, 2011). The name " $\mathrm{m}^{3}$ of fiber equivalent" is taken from Weimar (2009) and Bösch et al. (2015), while Mantau et al. (2010) and the forest department of UNECE/FAO (UNECE and FAO, 2010) use the term "solid wood equivalent" to refer to the same thing. The main advantage of using $\mathrm{m}^{3}$ of fiber equivalent compared to mass unit is that it is equivalent to $\mathrm{m}^{3}$ of roundwood in the case of greenwood (e.g, wood increment, harvest) 1

The wood fiber equivalent (refered to as $\mathrm{m}^{3}$ [f] in the text) is the volume of the wood fibers that are contained in the product at the fiber saturation point Weimar (2009). For each wood-based product (e.g., fiber board, plywood, pulp), a specific conversion factor is calculated depending on its primary measurement units. A section of the Supplementary Material is dedicated to a presentation of the formula and hypotheses used for this unit, with Figure 6 providing conversion factors for each product studied. Although similar in principle, our theoretical formula slightly differs from the one provided by Weimar (2009) in order to actually provide results expressed at the fiber saturation point. However, in practice, the lack of data (particularly concerning moisture rates) leads us to use the same factors for many products.

\subsubsection{Data sources}

Table 2.1.3 summarizes the sources used to build the MFA model. Data is taken from a number of different sources, which makes it very unlikely that it will "fit" the mass conservation law. However, to take advantage of all of the information available, we used a data reconciliation technique inspired by Cencic and Rechberger (2008).

\subsubsection{Uncertainty of input data and period of study}

Data quality is assessed either by directly retrieving precision indicators from the statistic sources, or, in most of the cases, on expert judgments based on the way data is built (source, type of survey or poll, scope of the study). Note that what matters the most for MFA results is the relative difference between data sources (e.g. source $a$ is twice as precise as source b). Estimated 95\% confidence intervals range from $1.4 \%$ (forest primary production) to $50 \%$ (wood logs used for individual heating, in official circuits).

Additionally, we chose to study the annual average between the years 2009, 2010, 2011, 2012 and 2013. This presents at least two advantages: first, it reduces the uncertainty (of data from polls), and second, it allows us to neglect stock variations, which would be very difficult to quantify otherwise. Indeed, in this type of capital-intensive industry, stocks of roundwood and final products are minimized to avoid high additional storage costs. Due to the high heterogeneity in timber sales practices (private and public, contacts and auctions) and the significant rate of informal transactions and re-selling of roundwood, it is not feasible to get information on stocks on any scale (Marty and Preget, 2010). In this study we consider that a fiveyears average is the best compromise for reducing the bias while remaining representative of the situation over a relatively short period of time.

\footnotetext{
${ }^{1}$ In addition, results are more easily conveyed to field experts and practitioners since they are used to work with this unit.
} 


\begin{tabular}{|c|c|c|}
\hline Item & Source & Comments \\
\hline $\begin{array}{l}\text { Biological increment / Total } \\
\text { harvest / Mortality }\end{array}$ & $\begin{array}{l}\text { French Geographic Institute } \\
\text { (IGN) }\end{array}$ & $\begin{array}{l}\text { Year average for the } 2009-2013 \text { pe- } \\
\text { riod. Available for each department } \\
\text { (nuts } 3 \text { level) }\end{array}$ \\
\hline $\begin{array}{l}\text { Harvest (commercial) and } \\
\text { harvest residues }\end{array}$ & $\begin{array}{l}\text { Annual agricultural statistics } \\
\text { (SSP) }\end{array}$ & $\begin{array}{l}\text { Available for each department and } \\
\text { for groups of species (coniferous } \\
\text { and broadleaves) and groups of uses } \\
\text { (roundwood, pulpwood and energy } \\
\text { wood) }\end{array}$ \\
\hline Firewood self-consumption & Ademe (2013) & $\begin{array}{l}\text { Survey on household wood con- } \\
\text { sumption }\end{array}$ \\
\hline $\begin{array}{l}\text { Production of sawnwood } \\
\text { and residues }\end{array}$ & $\begin{array}{l}\text { Annual agricultural statistics } \\
\text { (SSP) }\end{array}$ & $\begin{array}{l}\text { Available for each department and } \\
\text { for groups of species (coniferous } \\
\text { and broadleaves) }\end{array}$ \\
\hline $\begin{array}{l}\text { Production of other trans- } \\
\text { formed products }\end{array}$ & $\begin{array}{l}\text { Annual reports from federa- } \\
\text { tions (e.g. FCBA) }\end{array}$ & $\begin{array}{l}\text { Available at the country level, quan- } \\
\text { tities reported in specific units }\end{array}$ \\
\hline $\begin{array}{l}\text { Consumption of paper / pa- } \\
\text { per recycling rate }\end{array}$ & $\begin{array}{l}\text { Federation of paper produc- } \\
\text { ers }\end{array}$ & Available at the country level \\
\hline Outcome of wood wastes & INSEE & $\begin{array}{l}\text { The order of magnitude is highly } \\
\text { variable among available reports } \\
\text { underlining the fact that these quan- } \\
\text { tities are not known with precision. } \\
\text { For this study, we chose the official } \\
\text { Insee statistics. }\end{array}$ \\
\hline International trade & $\begin{array}{l}\text { SitraM database (based on } \\
\text { French customs) }\end{array}$ & $\begin{array}{l}\text { Available for } 382 \text { positions } \\
\text { (NST 2007), department of } \\
\text { origin/destination, country of } \\
\text { destination/origin. }\end{array}$ \\
\hline
\end{tabular}

Table 1: Data sources used for the MFA on wood products. 


\subsubsection{Supply and use tables and data reconciliation}

Physical Supply and Uses Tables (SUT) have a long tradition of being used in the fields of ecological economics and industrial ecology OECD (2008). They consist of product-industry matrices indicating:

- which local industries and/or foreign territories are supplying the product to the studied system (Supply Table),

- which local industries and/or foreign territories are using the product available in the studied system (Use Table).

Data reconciliation is used to phase out inconsistencies. The model imposes mass conservation laws, which implies constraints on the supply-use tables. In particular, supply equals use constraints must be verified for each product and for each transformation industry (the materials that enter an industry must also exit this industry, regardless of the products they are embodied in) as well. Equations of the constraints are provided in the supplementary material. As we explained before, these constraints are unlikely to be met by input data so we resort to data reconciliation. While details are provided in supplementary material, the principle can be summarized as follow: in order for the constraints to be fulfilled, output data (results) are allowed to differ from input data but the less uncertainty there is about the input data the smaller the distance between output and input data will be. SUTs at the level of France are provided in the supplementary material both before and after the data reconciliation process (Figures 5 and 6 in supplementary material).

\subsubsection{Uncertainty propagation}

We use Monte Carlo simulations to evaluate uncertainties of output results. As stated before, we assessed uncertainty of each input data. We use a Gaussian distribution hypothesis and expressed it in the form of $95 \%$ confidence interval (i.e. 2 standard deviations) $\sqrt{2}$

- Step 1: for each input variable (e.g., harvest of hard roundwood, production of hard sawnwood) we draw a realization based its Gaussian distribution 3 Given $i$ input data, we therefore have a random set of $i$ realizations.

- Step 2: this random set is used as input of the reconciliation process and leads to an output set, for instance composed of $j$ variables.

- Step 3 : steps 1 and 2 are repeated a sufficient number of times n (typically in our case, about 1000 times ${ }^{4}$.

- Step 4: for each of the $j$ output variables we analyze the output distribution ( $n$ realizations): output distributions are Gaussian as well and we use the standard deviation to estimate the $95 \%$ confidence interval of the output variable ( 2 standard deviations).

\footnotetext{
${ }^{2}$ The Gaussian hypothesis is the most commonly used in MFA data reconciliation processes (e.,g. Cencic, 2008).

${ }^{3}$ In fact, we add a subtlety by not allowing realizations outside 3 standard deviations ( $99 \%$ of the distribution) in order to prevent extreme values that would not make sense (the Gaussian distribution itself otherwise stretches from -infinity to +infinity).

${ }^{4} \mathrm{We}$ can plot the evolution of uncertainty estimation depending on the number of simulations to see when it has stabilized.
} 


\subsection{French Forest Sector Model (FFSM)}

\subsubsection{An overview of the model}

FFSM is a bio-economic recursive model of the French forest sector. The version used in this article is FFSM 1.0 (Caurla et al. 2013b a; Lecocq et al. 2011) 5 This version is composed of two modules: an inventory-based dynamics forest module (FD) and a partial equilibrium market module (MK). At each period (year), the MK module computes all market equilibria in the forest sector, from which it deducts the annual harvest. Harvest is then entered into the FD module, which computes available timber resources at year $t+1$. In turn, these results are then entered into the MK module, and so on (see Fig 1). To be consistent with our MFA, the base year is 2009 and the model runs until 2020.

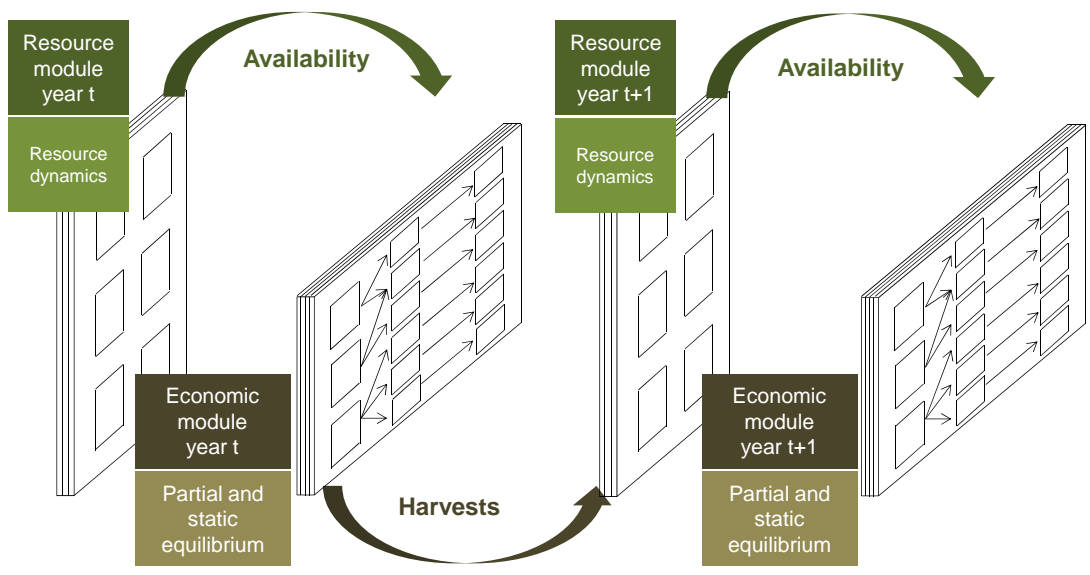

Figure 1: The FFSM is based on a recursive and modular framework (Caurla et al. 2013b). The time horizon is 2020.

\subsubsection{FD module}

The FD module represents the dynamics of the French forests that accounts for natural growth and mortality (Colin and Chevalier, 2009) and wood removals from human harvest. It simulates timber stock dynamics using a diameter-class approach. Since French forests are very diverse in terms of climate, soils, species and types of management, the FD module breaks down the timber resource into 1716 cells that differ by region (22 administrative regions), type of management (high forests, coppice, mixed), species

\footnotetext{
${ }^{5}$ The most recent version of the model (FFSM++; Lobianco et al. (2015. 2016) involves a third module, referred to as the microbased Area-Allocation module (AA) making it possible to project over longer horizons, and accounting for forest resource heterogeneity and the degree of forest owners expectations as well as their degree of risk-aversion.
} 
(coniferous and broadleaved) and diameter classes (a total of 13). Resource dynamics in each cell are calibrated using data from the 20052007 French forest inventories (Colin and Chevalier, 2009).

Between two successive years, the dynamics of wood volume for a specific cell follows the equation:

$$
V_{u, t+1}=V_{u, t} \times\left(1-t p_{u}-m_{u}-h_{u, t}\right)+V_{u-1, t} \times \beta_{u-1}
$$

where $V$ is the volume of wood, $u$ is the diameter class, $t$ is the time period (year), $t p_{u}$ is the time of passage for a tree in diameter class $u, m_{u}$ is the rate of natural mortality in diameter class $u, h_{u, t}$ is the harvest rate (derived from the economic module of the FFSM), and $\beta_{u-1}$ is a coefficient that accounts for the height growth of trees when upgrading from class $u-1$ to class $u$.

\subsubsection{MK module}

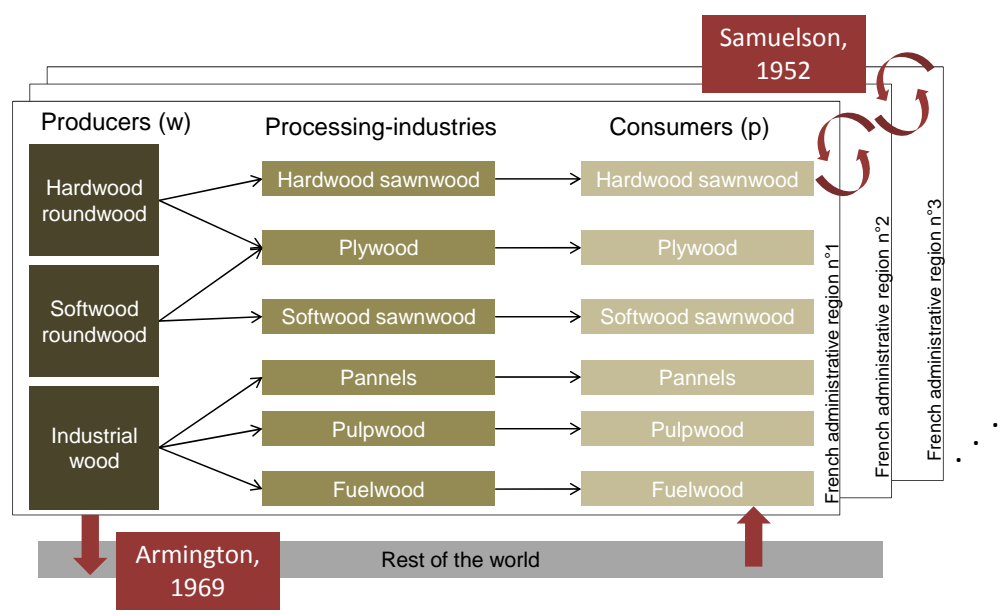

Figure 2: The economic module of the FFSM represents three levels of the forest sector and distinguishes nine products (Caurla et al. 2013b)

The MK module solves, for each French administrative region, a partial equilibrium problem according to Samuelson (1952) spatial price equilibrium framework. To do so, it annually computes (1) the optimal demand of processed products $p$ : sawnwood (hard and softwood, respectively referred to as hsw and ssw), plywood (pw), fuelwood (fw), pulp, panels and (2) the optimal supply of raw products $w$ : roundwood (hard and softwood, respectively referred to as HRW and SRW) and industrial wood (IW) and (3) the optimal prices associated to these quantities. This equilibrium explicitely accounts for wood availabilities in forest, for the costs of transformation in processing-indsutries and for the costs of transportation from one region to another into account following Samuelson (1952) theory. In addition, international trade is 
computed through an Armington framework assuming that domestic and foreign products are not fully substitutable. The international trade is modeled using exogenous international prices derived from the FAO (2013) and elasticities of substitution between local and international products specifically estimated for FFSM in Sauquet et al. (2011).

The regional supply $S$ of primary forest products $w$ in region $i$ takes the form of Eq. 2, where $\epsilon_{w}$ is the elasticity of supply to price $P_{w, i, t}$ and $\beta_{w}$ is the elasticity of supply to available resources in forest. Both elasticities are derived from Buongiorno et al. (2003) and are exogenous in the context of this study.

$$
S_{w, i, t}=S_{w, i, t-1}\left(\frac{P_{w, i, t}}{P_{w, i, t-1}}\right)^{\epsilon_{w}}\left(\frac{F_{w, i, t}}{F_{w, i, t-1}}\right)^{\beta_{w}}
$$

Likewise, in each region $i$, the demand curves $D$ of processed products $p$ use exogenous elasticities $\sigma_{p}$ of demand to price (specifically estimated for FFSM in Sauquet et al. (2011)).

$$
D_{p, i, t}=D_{p, i, t-1}\left(\frac{P_{p, i, t}}{P_{p, i, t-1}}\right)^{\sigma_{p}}
$$

Eventually, a Leontief function represents the transformation of raw products into processed product: 6 (see Table 4 in Appendix). Compared to a single Leontieff matrix, FFSM makes thus it possible to deal with nonlinear relationships between the supply and demand levels and the prices of wood products.

\subsubsection{Consistency with MFA and input-output calibration in FFSM}

The number of products represented in FFSM is lower than in MFA analysis. To make the modeling framework consistent, results from MFA are aggregated to match the definition of products in FFSM. Inputoutput coefficients used in the Leontief function of FFSM are then calibrated using MFA results for each group of products. They are presented in Table 4 in the Supplementary Material.

\subsubsection{Prospective: simulating policies to relocate sawmill activities}

Several papers assess the impacts of export restrictions on global and national forest sectors. Using a global log-lumber trade model, Van Kooten and Johnston (2014) show that moving an export tax at the national level (Canada or Russia) has a small impact on the global forest sector welfare. Using data for the State of Washington, Johnson et al. (1995) suggest that domestic mills and consumers clearly benefit from the ban while the welfare of Japanese consumers and the export industry is reduced. The same conclusion holds in Van Kooten and Johnston (2014) for British Columbia (BC). They report that, while free trade of logs might maximize global wellbeing, it might also reduce the domestic welfare of economic forest sector agents. While these papers clearly suggest that export bans are beneficial to the domestic forest sector, neoclassical economy judges them inefficient at the global scale (Goodland and Daly, 1996). However, these studies focus on the impacts of a restriction without analyzing the different design of policy options to reduce export and their implications on forest sectors. This is precisely the aim of the prospective part of this paper. To do this, we tested three alternative policies. Two of them consist in subsidizing transformed products made of roundwood: $S u b_{-} C$ is a subsidy to domestic sawnwood and plywood consumption, while $S u b_{-} T$ is a subsidy to sawnwood and plywood transformation. The other policy, referred to as Exp, is an extra-cost to roundwood export. $S_{u} b_{-} C$ and $S_{u} b_{-} T$ differ from their transmission channels: while $S_{u} b_{-} C$

\footnotetext{
${ }^{6}$ In addition, the model considers sawmills and harvest residues as by-products of primary activities.
} 
acts through processed product consumers, $S_{u} b_{-} T$ directly irrigates the upstream and the downstream of the roundwood sector through the reduction of transformation costs.

More precisely, Sub_C is introduced in Eq. 3 such as:

$$
D_{p, i, t}=D_{p, i, t-1}\left(\frac{P_{p, i, t} \times S u b_{-} C_{p, i, t}}{P_{p, i, t-1} \times S u b_{-} C_{p, i, t-1}}\right)^{\sigma_{p}}
$$

Sub_T is introduced in the transformation agents surplus, in the objective function of FFSM, decreasing $C_{p, w}$, the cost of transforming products $w$ in products $p$.

Exp acts differently and models an extra cost for plant-health control and preventive treatment. Such a policy already exists for wood packaging material (Strutt et al. 2013) as a tool to limit the diffusion of pests and diseases. We assume that this policy costs $10 € / \mathrm{m}^{3}$ which is close to the export tax equivalent imposed by Canada on its exports to the U.S. (Van Kooten and Johnston, 2014) and which is considered as plausible by the French government. In the model, this policy is introduced indirectly by increasing international prices by $10 € / \mathrm{m}^{3}$. This value leads to a reduction of roundwood log exports of $20 \%$ regarding a baseline scenario without policy. To make the comparison between policies meaningful, we based them on the same level of export reduction derived from the Exp policy result (-20\% for roundwood, either hardwood or softwood). We calibrated the levels of subsidies $S u b_{-} C$ and $S u b_{-} T$ consistent with this objective by a trial and error process (55\% and $110 \%$, respectively).

\section{Results}

\subsection{Wood flow analysis}

MFA results are presented in two figures: Figure 3 provides a global view of the upstream part of the supply chain (forest stock, increment, harvest, self-consumption of households, etc.) and Figure 4 focuses on the transformation of lumber and industrial and pulpwood 7 . Every flow comes with a figure that specifies the quantity of wood in $\mathrm{m}^{3}(\mathrm{f})$. Besides, following Schmidt (2008) we specify the volumes of import and export for each product. They are represented as vertical input (import) and output (export) flows on the Sankey diagrams. Confidence intervals are also represented as well as some quantities in a more intelligible unit, e.g., paper production is expressed in tonnes.

Six main outcomes stem from the diagrams. First, Figure 3 shows that, at the national level, the stock of standing wood is increasing since the total of harvested wood (including self-consumption) represents about half of the annual increment. Although this result is in line with figures published elsewhere (Colin and Thivolle-Cazat 2016), it must be qualified since all biological production at the national level cannot be harvested. Indeed, some species or diameters do not have a commercial outlet and some areas, such as mountainous ones, are inaccessible. This can explain the paradoxical situation encountered in many French regions where forest stocks increase while wood harvest seems to reach a ceiling. In addition, as suggested by its wide confidence interval, the production of energy wood remains difficult to assess. The majority of energy wood flowing in anthropogenic activities is composed of self-consumption energy wood. These self-consumption volumes are estimated by Pouet and Gauthier (2013) based on a poll taken on some 1,500 households. Even if the total household consumption probably gives a fair idea of the situation, quantifying the share of the different firewood supply chains is more difficult since some suppliers may have an interest

\footnotetext{
${ }^{7}$ The global input flow in Figure 4 corresponds to the combination of all roundwood and pulpwood/industrial wood flows on Figure 3
} 


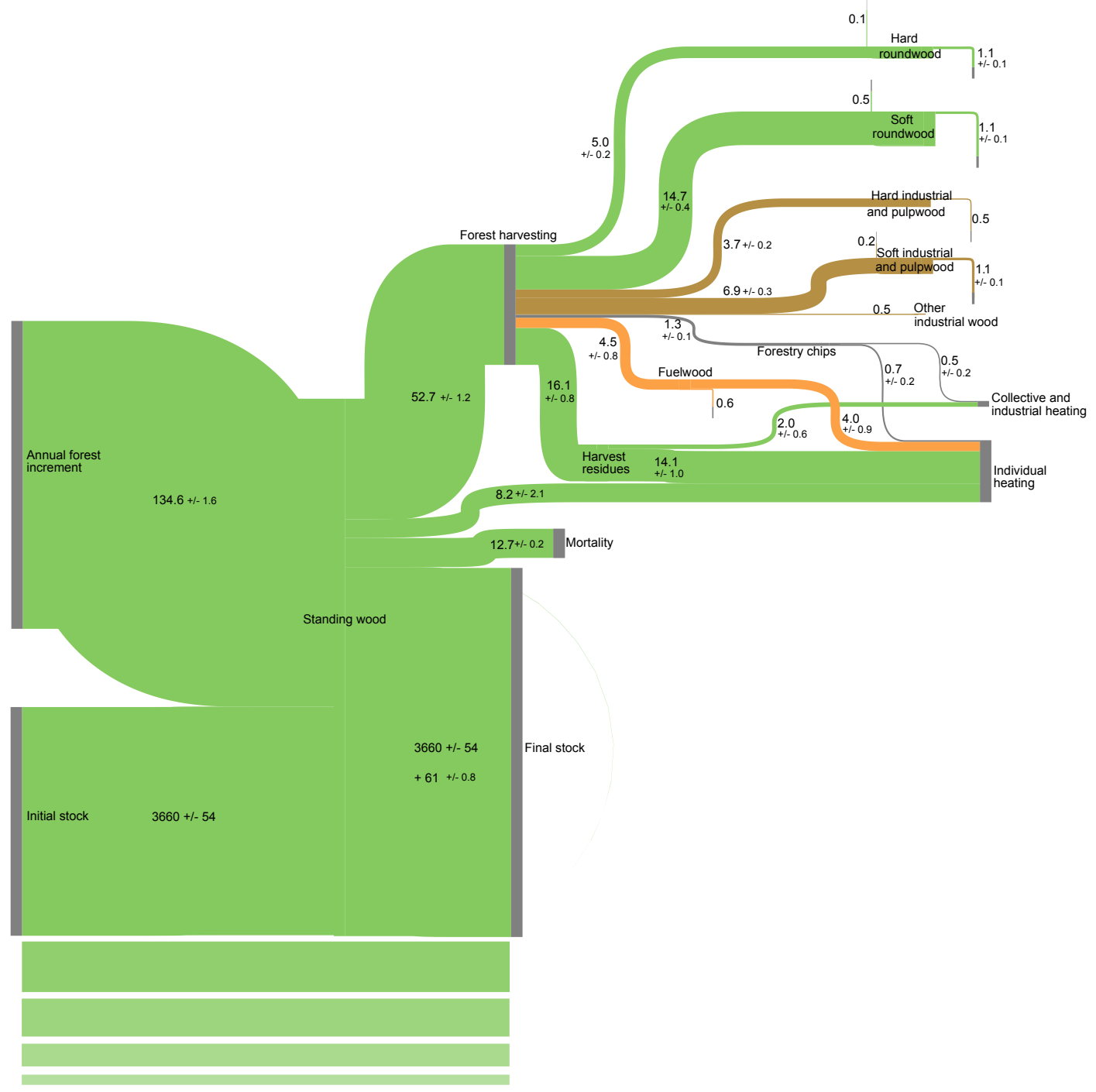

Figure 3: Sankey diagram of the upstream part of the forest-wood MFA. Flows are expressed in $\mathrm{Mm}^{3}$ (f) and correspond to a one-year average during the period 2009-2013. Wood stock is not represented at the same scale as the other flows. Besides, initial stock and its associated uncertainty is not an output from the model (that does not handle stocks) but is directly retrieved from IGN. 


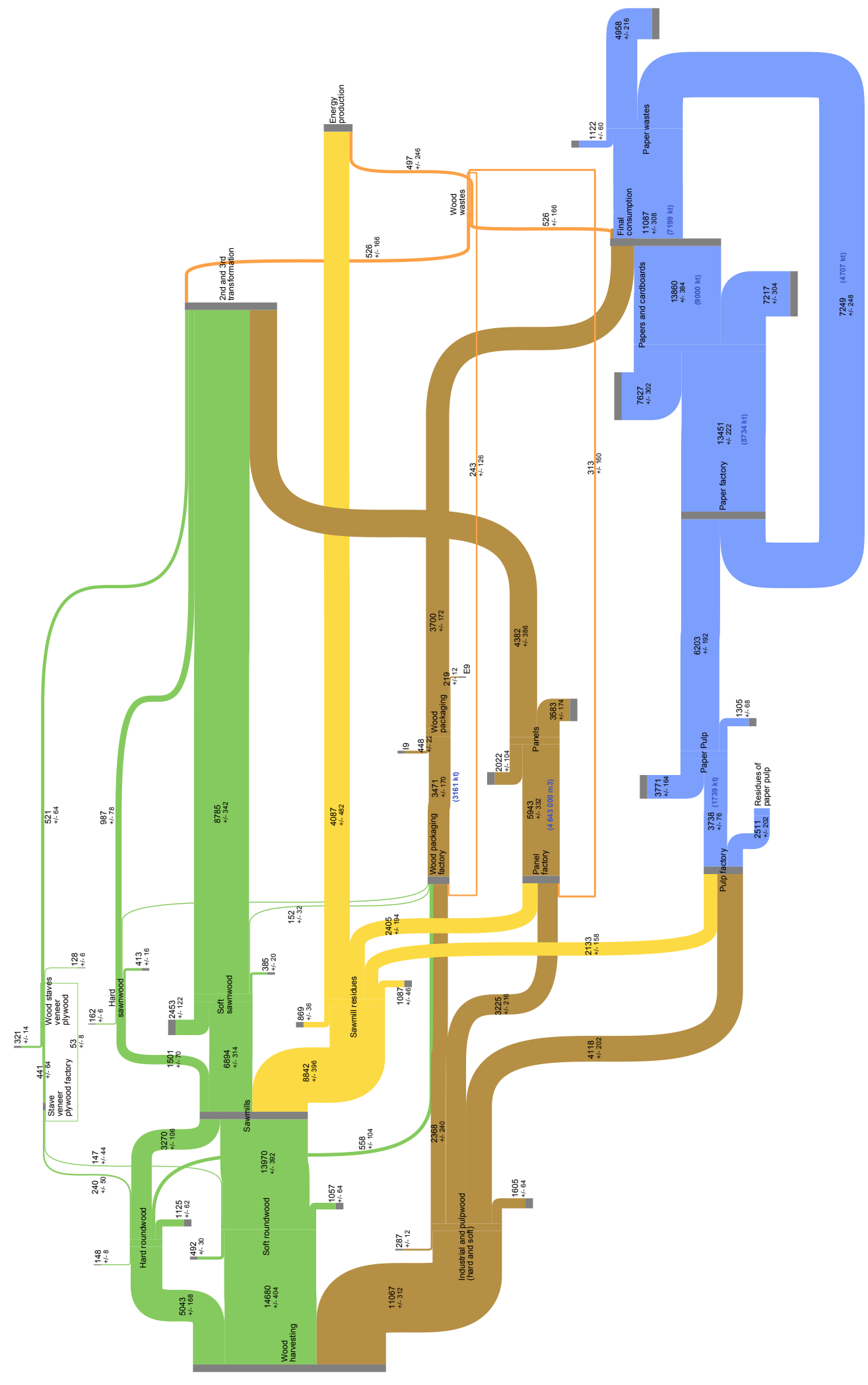

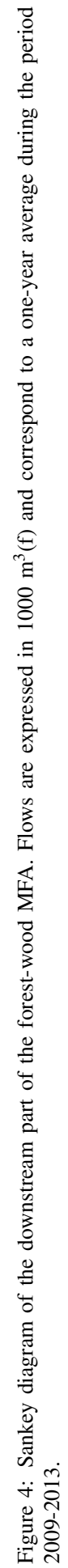


in under-reporting their sales. In addition, the core business of energy wood suppliers is often logging or sawmilling, which makes the identification of energy wood flows even more complex (INSEE, 2014).

Second, although the standing wood resource at national level is mostly composed of broadleaves (about 63\% (FCBA, 2013)), it appears that HRW represents 9.5\% of log volumes, wheareas SRW accounts for $28 \%$. This result is explained by the higher adequacy of softwood with the process industry requirements. Indeed, sawmills consume about four times more SRW than HRW, and the panel and paper pulp industries nearly twice as much.

Third, France is a net exporter of logs. This is all the more true for hardwood. Exports represent $22 \%$ of total HRW and 7\% of total SRW. France is also a net exporter of pulpwood since about $15 \%$ of the pulpwood harvest is exported.

Fourth, Figure 4 suggests that ssw represents the largest production in volume closely followed by panels production. Half of the sawmill residues are used in the pulp and panel industries as raw material, which reveals a well-established recovery chain and potential competition with new additional fuelwood demand. The pulp and paper sectors have a large recycling chain: more than $80 \%$ of papers consumed are sorted to be recycled, representing about $55 \%$ of the resources of the paper industry (expressed in volume of wood fiber equivalent). These sectors determine the economic value of the wood sector in France. It can be noted that France also exports large quantities of paper wastes that are therefore not valued in the country.

Fifth, Figure 7 in the Supplementary Material shows that niche products such as stave woods and plywood, even if negligible from a volume point of view, remain important from a value-added perspective. Conversely, the weight of sawmill residues is strongly reduced. Note that these niche products are mainly produced from HRW and could become interesting outlets from the point of view of export reduction.

Sixth, from a trade balance perspective, we can notice that panels and paperboards are largely exported (resp. $60 \%$ and $54 \%$ of the total production is exported). Hardwood sawmilling is also a net exporter, which shows a possible commercial outlet for producing hsw in France for export. On the contrary, 28\% of total ssw consumed in France is imported which shows an inadequacy between local supply and demand. Imported products are likely to be species and/or diameters that are not produced in France (even if data cannot corroborate this assumption).

These results mask important regional differences. For example, about half of the wood harvest takes place in only five regions (of the 22 French regions). These regions are not analyzed in this article, which focuses on diagnosis and prospective for the national forest-wood supply chain, although they constitute major leads for future work. We will come back to this question in the conclusion.

\subsection{Prospective}

We assessed the impacts of the policies described above on two groups of economic indicators: (i) the variations in prices and quantities produced, consumed, imported and exported, and (ii) the budgetary cost and the variations in economic agent surpluses. Variations are given for the year 2020. Sankey diagrams outlining the potential impact of each policy on material flows are proposed in the Supplementary Material (Figures 8,9 and 10 .

\subsubsection{Impacts on quantities}

Table 2 shows the impacts of the three policies on production and consumption of wood products in the sector. Three outcomes stem from these results. First, while $S u b_{-} C$ and $S u b_{-} T$ largely modify production and consumption patterns, Exp does not have a major impact on domestic wood flows. It only slightly reduces HRW and SRW production. This is because Exp acts via an extra cost on export without modifying domestic prices and domestic agents' behaviors. As a consequence, total roundwood production decreases because of export reduction but this does not lead to a rebound effect on the domestic market. Second, while 


\begin{tabular}{|l|l|l|l|l|l|l|l|l|l|}
\hline & $\begin{array}{l}\text { HRW } \\
(\mathrm{P})\end{array}$ & $\begin{array}{l}\text { SRW } \\
(\mathrm{P})\end{array}$ & IW (P) & fw (C) & $\begin{array}{l}\text { hsw } \\
(\mathrm{C})\end{array}$ & ssw (C) & pw (C) & $\begin{array}{l}\text { pulps } \\
(\mathrm{C})\end{array}$ & $\begin{array}{l}\text { panels } \\
(\mathrm{C})\end{array}$ \\
\hline Baseline & 5.04 & 14.68 & 11.07 & 24 & 0.99 & 8.76 & 0.52 & 6.2 & 4.38 \\
\hline Sub_C & 7.16 & 18.06 & 8.85 & 25.44 & 1.71 & 11.64 & 0.66 & 6.33 & 4.43 \\
& $(+42 \%)$ & $(+23 \%)$ & $(-20 \%)$ & $(+6 \%)$ & $(+73 \%)$ & $(+33 \%)$ & $(+26 \%)$ & $(+2 \%)$ & $(+1 \%)$ \\
\hline Exp & 4.79 & 14.39 & 11.18 & 24 & 0.99 & 8.76 & 0.52 & 6.2 & 4.38 \\
& $(-5 \%)$ & $(-2 \%)$ & $(+1 \%)$ & $(0 \%)$ & $(0 \%)$ & $(0 \%)$ & $(0 \%)$ & $(0 \%)$ & $(0 \%)$ \\
\hline Sub_T & 7.16 & 17.62 & 9.07 & 23.04 & 1.36 & 9.72 & 0.76 & 6.27 & 4.43 \\
& $(+42 \%)$ & $(+20 \%)$ & $(-18 \%)$ & $(+4 \%)$ & $(+38 \%)$ & $(+11 \%)$ & $(+45 \%)$ & $(+1 \%)$ & $(+1 \%)$ \\
\hline
\end{tabular}

Table 2: Quantities produced (P) or consumed (C) in 2020 compared (variations compared to the baseline scenario) in $\mathrm{Mm}^{3}[\mathrm{f}]$.

\begin{tabular}{|l|l|l|l|l|l|l|l|l|l|}
\hline & $\begin{array}{l}\text { HRW } \\
(\mathrm{E})\end{array}$ & $\begin{array}{l}\text { SRW } \\
(\mathrm{E})\end{array}$ & IW (E) & fw (I) & hsw (I) & ssw (I) & pw (I) & $\begin{array}{l}\text { pulps } \\
(\mathrm{I})\end{array}$ & $\begin{array}{l}\text { panels } \\
(\mathrm{I})\end{array}$ \\
\hline Baseline & 1.13 & 1.06 & 1.61 & 0 & 0.16 & 2.45 & 0.32 & 3.77 & 2.02 \\
\hline Sub_C & 1.26 & 1.04 & 0.13 & 0 & 0.05 & 1.09 & 0.15 & 1.06 & 0.91 \\
& $(-20 \%)$ & $(-20 \%)$ & $(-3 \%)$ & $(-2 \%)$ & $(+83 \%)$ & $(+42 \%)$ & $(+29 \%)$ & $(-1 \%)$ & $(0 \%)$ \\
\hline Exp & 0.85 & 0.85 & 0.17 & $0(0 \%)$ & 0.15 & 2.12 & 0.3 & 1.14 & 0.94 \\
& $(-20 \%)$ & $(-20 \%)$ & $(0 \%)$ & & $(0 \%)$ & $(0 \%)$ & $(0 \%)$ & $(0 \%)$ & $(0 \%)$ \\
\hline Sub_T & 1.23 & 1.02 & 0.14 & 0 & 0.06 & 1.55 & 0.06 & 1.08 & 0.92 \\
& $(-20 \%)$ & $(-20 \%)$ & $(-3 \%)$ & $(-2 \%)$ & $(0 \%)$ & $(-7 \%)$ & $(-24 \%)$ & $(-1 \%)$ & $(0 \%)$ \\
\hline
\end{tabular}

Table 3: Exports of raw products and imports of transformed products in 2020 (variations regarding baseline without policy) in $\mathrm{Mm}^{3}[\mathrm{f}]$.

\begin{tabular}{|l|l|l|l|l|l|l|l|l|l|}
\hline & $\begin{array}{l}\text { HRW } \\
(\mathrm{P})\end{array}$ & $\begin{array}{l}\text { SRW } \\
(\mathrm{P})\end{array}$ & IW (P) & fw (C) & $\begin{array}{l}\text { hsw } \\
(\mathrm{C})\end{array}$ & ssw (C) & pw (C) & $\begin{array}{l}\text { pulps } \\
(\mathrm{C})\end{array}$ & $\begin{array}{l}\text { panels } \\
(\mathrm{C})\end{array}$ \\
\hline Sub_C & $+93 \%$ & $+41 \%$ & $-30 \%$ & $+7 \%$ & $+47 \%$ & $+35 \%$ & $+46 \%$ & $+2 \%$ & $+1 \%$ \\
\hline Exp & $-10 \%$ & $-6 \%$ & $+1 \%$ & $0 \%$ & $0 \%$ & $0 \%$ & $0 \%$ & $0 \%$ & $0 \%$ \\
\hline Sub_T & $+88 \%$ & $+36 \%$ & $-25 \%$ & $+6 \%$ & $+34 \%$ & $+13 \%$ & $+34 \%$ & $+1 \%$ & $+1 \%$ \\
\hline
\end{tabular}

Table 4: Variations in surpluses (C: consumers surpluses; P: producers surpluses) regarding baseline scenario without policy in 2020.

\begin{tabular}{|l|l|l|l|}
\hline & $\begin{array}{l}\text { Total welfare vari- } \\
\text { ations compared to } \\
\text { baseline (M€) }(+ \\
\text { means a net gain, - } \\
\text { means a net loss) }\end{array}$ & $\begin{array}{l}\text { Budgetary costs } \\
(\mathrm{M} €)\end{array}$ & $\begin{array}{l}\text { Social costs (bud- } \\
\text { getary costs - Total } \\
\text { welfare variations, } \\
\mathrm{M} €)\end{array}$ \\
\hline Sub_C & +2248 & +3000 & +752 \\
\hline Exp & -33 & 0 & +33 \\
\hline Sub_T & +1448 & +1653 & +205 \\
\hline
\end{tabular}

Table 5: Impacts on welfare, budgetary costs and social costs. 
$S_{u} b_{-} C$ and $S_{u} b_{-} T$ have almost the same impact on the production of raw products upstream, their impacts on consumption patterns differ. In fact, the impacts of $S u b_{-} C$ mostly depend on the price elasticity of the transformed product demand and the price elasticity of the primary product supply. Since the demand of hsw $(-0.5)$ is more elastic than that of ssw $(-0.4)$ and pw (-0.3) and the supply of HRW is more elastic than that of SRW (1.2 vs. 0.9), Sub_C has a relatively bigger impact on hsw than ssw. For its acts, Sub_T plays via the costs of transformation so that the higher the cost of transformation is, the higher the impact of Sub_T will be. This explains the higher impact on plywood (cost of transformation: $534 € / \mathrm{m}^{3}$ ) than on hardwood sawnwood $\left(268 € / \mathrm{m}^{3}\right)$ and on softwood sawnwood ( $\left.48 € / \mathrm{m}^{3}\right)$. Third, although Sub_C and Sub_T are subsidies of the sawnwood and plywood sectors, they also impact fuelwood and, to a lesser extent, the pulp and panel sectors via the increase in production of sawmill residues. This implies a crowding-out effect with IW, which results in a reduction of IW production (-20\% and $-18 \%$, respectively) that is not observed with $\operatorname{Exp}$ policy.

Regarding impacts on exports and imports, Table 3 shows that $S u b_{-} C$ increases imports of hsw, ssw and pw in a proportion depending on the price elasticity of the demand. Sub_C therefore creates an important windfall effect. On the other hand, Sub_T decreases imports of ssw and pw and does not affect imports of hsw. This is because $S_{u b} T$ only acts on domestic production costs, which makes domestic products more competitive than foreign substitutes.

\subsubsection{Variation of surpluses and budgetary costs}

Table 4 shows that while the two subsidies increase all surpluses except the surplus related to IW production Exp reduces surplus related to HRW/SRW productions, slightly increases surplus related to IW production and has no significant impact on surpluses related to consumption activities. In the case of Sub_T, the driver is the reduction of transformation costs that reduces the consumer price and increases the producer price and, as a consequence, increases both the quantities produced and consumed at the national scale. This results in overall gains in economic agents' surplus. In the $S u b \_C$ case, the consumer-perceived price is reduced which leads to a higher demand and, therefore, an increase in production upstream. In that case, however, part of the additional demand is fulfilled by imports, as shown in the previous section, which do not increase domestic agents' surplus. Both subsidies have a negative impact over industrial wood activities since they lead to an additional production of sawmill residues, leading to a crowding-out effect with industrial wood upstream.

Table 5 shows that while $S_{1} b_{-} C$ is the subsidy leading to a higher welfare benefits, it is also the most expensive. When looking at the social costs, $S u b_{-} T$ performs better than $S u b_{-} C$ since $S u b_{-} T$ does not increase imports and does not not imply a windfall effect. Budgetary costs of Exp are 0 since FFSM does not take transaction costs into account.

\subsubsection{Discussion about the results}

Results show there is no first best policy option. From a policy-making perspective, the implementation of a policy to reduce roundwood export must consider the different levels of impacts, namely the welfare variations for each economic segment, the total welfare costs, and the total budgetary costs. Sub_C leads to the highest welfare gains for economic agents (except IW suppliers) but is the most costly for the government budget because of the windfall effect. Sub_T follows a comparable surplus gains pattern while being half as expensive. Exp policy is not beneficial to wood sector surplus but is the least costly if we assume that the transaction and functioning costs are covered by the payment made by roundwood exporters. In addition, it is the only policy in which the IW sector remains unchanged. According to these results, the only possible solution for (1) reducing the crowding out effect between sawmill residues and industrial wood competition with the pulpwood sector, and (2) increasing welfare surplus in the forest sector while (3) preventing a 
windfall effect would be to combine Exp with Sub_T. Figure 11 in the Supplementary Material shows the effect of a range of combinations between these two policies on social cost. However, as outlined before, social cost is not the only criterion to be considered. The choice of a policy mix should imply a debate among all stakeholders impacted by the policy (e.g., including citizens paying for the potential subsidies). We believe that they alone can express which criteria matter the most and which efforts they are willing to make.

In addition, since FFSM has no endogenous growth module, it cannot represent the impacts of subsidies on capital accumulation. Yet, it is very likely that, in reality, when looking at the long term, the net social costs of policies would diminish over time as capital investments increase. At one point, the net social costs may even become negative.

\section{Conclusion}

Our paper fills two important gaps. It is the first in the literature to draw a comprehensive picture of wood flows in the upstream part of the wood sector in France that takes all available data sources into account. To do this, we built an MFA model using a reconciliation process and a homogeneous unit to make the different sources consistent and comparable while quantifying uncertainty. Second, it assesses the economic impacts of three policy alternatives to reduce exports of logs by using FFSM, a partial equilibrium model. Impacts on material flows are evaluated as well. By combining an MFA and an economic modeling framework, our analysis goes beyond diagnosis and proposes insights into policy-makers' recommendations.

We demonstrated the relevance of MFA to reconcile highly heterogeneous datasets. Since no common database exists in the forest-wood sector, these results offer a solid base for analysis and opportunities for development prospects. However, attention must be paid to the temporal aspects of the study. Our MFA provides a snapshot of the situation for a specific reference year and does not capture trends. For instance, concerns on raw wood leaks are not only due to current export levels but also, and maybe mostly, to increasing exports trends and sawmill shut-downs. Thus, it would be relevant to repeat the study according to a predetermined time-step (e.g., 5 years using either a fixed or sliding average), using the same methodology. Comparison across time of wood flow dynamics may be encouraged as a tool to study the wood-forest sector's health and as a powerful monitoring instrument for policy makers. The systematic framework implemented here will hopefully foster this endeavor.

MFA results suggest that while broadleaves dominate conifers in French forests, production of HRW is three times lower than that of SRW. Meanwhile, exports represent $22 \%$ of the total HRW production but only $7 \%$ of SRW production. This leads to an apparent paradox: the resource is abundant and potentially underharvested but the sector is unprofitable since part of the value added is created abroad. Nevertheless, the MFA suggests that both hsw production and niche products such as stave wood are a potential commercial outlet for domestic HRW. Yet, as long as the international demand for logs and especially broadleaf products is the driving force behind exports, production of HRW will be oriented toward exportation and investments in the sector will be postponed, exacerbating the trade balance deficit. With this in mind, as the second step of our analysis, we tested three policy options to reduce log exports: a subsidy to consumers, a subsidy to process industries and an additional costs to export due to phytosanitary control, which acts as a ban in the model. The potential effects of these policies help to specify several criteria of interest to aid the decision process: budget costs, welfare variation in the forest-wood sector and redistribution of this welfare among agents. These indicators could also serve to assess potential impacts on local employment given that labor intensiveness differs between sectors. Moreover, a healthier, more dynamic supply chain would arguably make it easier to reach national climate mitigation goals. These last two points would require more in-depth studies but seem crucial if we are to have a holistic view of the sector. While mono-criterion optimization 
approaches (e.g., optimizing cost-effectiveness) are often used to make policy recommendations, we believe that multi-criteria analysis would be better suited to study possible alternatives. This approach would go hand-in-hand with a decision process involving all of the stakeholders, that is, ideally, anyone affected by the decision, where they are asked what they value most and what compromises they are willing to accept and support.

Although this was not the purpose of this article, we know that the forest-wood sector is highly geographically heterogeneous. Therefore, similar studies at regional levels would be beneficial. Rather than a series of individual regional assessments, we would argue for a coherent multi-regional assessment, that is, disaggregating the national MFA and economic model to provide evaluations in all regions. Regional strategies, e.g., specialization strategies, could then be revisited both in terms of their internal effects and consequences on other regions. Interestingly, there is no guarantee that the same policy would be preferred, regardless of whether the focus is put on the national level or on the regional level. We think that a multi-regional approach will therefore be a major direction for future research. Nevertheless, one limitation that should be kept in mind when reproducing such a study is the possible bias induced by the scale effect. Indeed, working at a national scale and on a five-years average reduces the impact of potential extreme regional events (such as forest fires, storm or pest outbreaks). This homogeneizing effect would not be relevant at a lower level, for example when downscaling the computation at regional level and may lead to faulty conclusions due to misinterpretation. It is thus necessary to put the MFA results in a meaningful and broader context when looking at local flows arrangement. This should stand for any local MFA.

This work was supported by the French Ministry of Agriculture (Programme 215 du MAAF). The authors thank Mélanie Lucas from DRAAF for her valuable comments. The authors thank Alexandra Niedzwiedz from AgroParisTech for her support in data management. 


\section{Bibliography}

Alexandre, S., 2017. Rapport de mission de la déléguée interministérielle à la forêt et au bois. Tech. rep., CGEDD.

Bais, A., Lauk, C., Kastner, T., Erb, K., 2015. Global patterns and trends of wood harvest and use between 1990 and 2010. Ecological Economics 119, 326-337.

Binder, C., 2007. From material flow analysis to material flow management part i: social sciences modeling approaches coupled to mfa. Journal of Cleaner Production 15(17), 1596-1604.

Binder, C., Hofer, C., Wiek, A., Scholz, R., 2004. Transition towards improved regional wood flows by integrating material flux analysis and agent analysis: the case of appenzell ausserrhoden, switzerland. Ecological Economics 49(1), 1-17.

Binder, C., Van Der Voet, E., Rosselot, K., 2009. Implementing the results of material flow analysis. Journal of Industrial Ecology 13(5), 643-649.

Bouman, M., Heijungs, R., van der Voet, E., van den Bergh, J., Huppes, G., 2000. Material flows and economic models: an analytical comparison of sfa, lca and partial equilibrium models. Ecological Economics $32(2), 195-216$.

Bringezu, S., Moriguche, Y., 2002. Material flow analysis. In Ayres RU, Ayres LW (eds). A Handbook of Industrial Ecology. Edward Elgar, Cheltenham.

Brunner, P., Rechberger, H., 2003. Practical handbook of material flow analysis, 1st edition. CRC Press, Baca Raton, FL.

Burström, F., Korhonen, J., 2001. Municipalities and industrial ecology: reconsidering municipal environmental management. Sustainable Development 9, 36-46.

Bösch, M., Jochem, D., Weimar, H., Dieter, M., 2015. Physical input-output accounting of the wood and paper flow in germany. Resources, Conservation and Recycling 64, 99-109.

Caurla, S., Delacote, P., Lecocq, F., Barkaoui, A., 2013a. Combining an inter-sectoral carbon tax with sectoral mitigation policies: Impacts on the french forest sector. Journal of Forest Economics 19(4), 450 461.

Caurla, S., Lecocq, F., Delacote, P., Barkaoui, A., 2013b. Stimulating fuelwood consumption through public policies: An assessment of economic and resource impacts based on the french forest sector model. Energy Policy 63, 338-347.

Cencic, O., Rechberger, H., 2008. Material flow analysis with software stan. J. Environ. Eng. Manag. 18(1), $3-7$.

Cheng, S., Xu, Z., Su, Y., Zhen, L., 2010. Spatial and temporal flows of china's forest resources: development of a framework for evaluating resource efficiency. Ecological Economics 69(7), 1405-1415.

Chevallier, L., Forot, V., Rouillon, A., 2014. Etude de faisabilité pour l'évaluation des flux de matière de biomasse. Tech. rep., ADEME, FranceAgrimer. 
Colin, A., Chevalier, H., 2009. Rapport technique module biologique LEF. Tech. rep., Inventaire Forestier National.

Colin, A., Thivolle-Cazat, A., 2016. Disponibilités forestières pour l'énergie et les matériaux à l'horizon 2035. Tech. rep., IGN, FCBA, ADEME.

Courtonne, J.-Y., Alapetite, J., Longaretti, P.-Y., Dupré, D., Prados, E., 2015. Downscaling material flow analysis: the case of the cereals supply chain in france. Ecological Economics 118, 67-80.

Ehrenfled, J., 2004. Industrial ecology: a new field or only a metaphor? Journal of Cleaner 12, 824-831.

Erkman, S., 1997. Industrial ecology: an historical view. Journal of Cleaner Production 5, 1-10.

FCBA, 2013. Mémento. URL http://www.fcba.fr/sites/default/files/files/memento_2013.pdf

Gibbs, D., Deutz, P., Proctor, A., 2005. Industrial ecology and eco-industrial development: A potential paradigm for local and regional development? Regional Studies 39(2), 171-183.

Goodland, R., Daly, H., 1996. If tropical log export bans are so perverse, why are there so many? Ecological Economics 18, 189-196.

Hashimoto, S., Moriguchi, Y., 2004. Data book: Material and carbon flow of harvested wood in japan. center for global environmental research. Tech. rep., National Institute for Environmental Studies, Tsukuba.

Hekkert, M. P., Joosten, L. A. J., Worrell, E., 2000. Analysis of the paper and wood flow in the netherlands. Resources, Conservation and Recycling 30(1), 29-48.

IGN, 2016. Le memento inventaire forestier. la foret en chiffres et en cartes. Tech. rep., National Institute of Geographic and Forestry Information, Paris.

INSEE, 2014. La filière forêt-bois en franche-comte - edition 2013. Tech. rep., Les dossiers de l'INSEE Franche-Comté, $30 \mathrm{p}$.

Johnson, R., Rucker, R., Lippke, H., 1995. Expanding u.s. log export restrictions: impacts on state revenue and policy implications. Journal of Environmental Economics and Management 29, 197-213.

Knaggs, G., O’Driscoll, E., 2008. Estimated woodflow for the republic of ireland in 2007. Tech. rep., COFORD Processing / Products No 18.

Lecocq, F., Caurla, S., Delacote, P., Barkaoui, A., Sauquet, A., 2011. Paying for forest carbon or stimulating fuelwood demand? insights from the french forest sector model. Journal of Forest Economics 17(2), $157-168$.

Lobianco, A., Delacote, P., Caurla, S., Barkaoui, A., 2015. The importance of introducing spatial heterogeneity in bio-economic forest models: Insights gleaned from ffsm++. Ecological Modelling 309-310, 82-92.

Lobianco, A., Delacote, P., Caurla, S., Barkaoui, A., 2016. Accounting for active management and risk attitude in forest sector models. an impact study on french forests. Environmental Modeling and Assessment 21(3), 391-405. 
Mantau, U., 2012. Wood flows in europe (eu27). Tech. rep., Project report. celle 2012.

Mantau, U., 2015. Wood flow analysis: quantification of resource potentials, cascades and carbon effects. Biomass and Bioenergy 73, 28-38.

Mantau, U., Saal, U., Prins, K., Steierer, F., Lindner, M., Verterk, H., Eggers, J., Leek, N., Oldenburger, J., Asikainen, A., Anttila, P., 2010. Euwood - real potential for changes in growth and use of eu forests. final report. Tech. rep.

Marty, G., Preget, R., 2010. A socio-economic analysis of french public timber sales. Journal of Sustainable Forestry 29, 15-49.

METLA, 2011. Wood flows in finland 2010. finnish statistical yearbook of forestry. Tech. rep., METLA.

OECD, 2008. Measuring material flows and resource productivity - synthesis report. Tech. rep., OECD. URL http: //wwW . oecd.org/env/indicators-modelling-outlooks/MFA-Synthesis.pdf

Parobek, J., Palus, H., Kaputa, V., Supin, M., 2014. Analysis of wood flows in slovakia. BioResources 9(4), 6453-6462.

Patricio, J., Kalmykova, Y., Rosado, L., Lisovskaja, V., 2015. Uncertainty in material flow analysis. indicators at different spatial levels. Journal of Industrial Ecology 19(5), 837-853.

Piskur, M., Krajnc, N., 2007. Roundwood flow analysis in slovenia. Croatian Journal of Forest Engineering 28(1), 39-46.

Pouet, J.-C., Gauthier, A., 2013. Etude sur le chauffage domestique au bois : marché et approvisionnement. Tech. rep., ADEME.

Samuelson, P., 1952. Spatial price equilibrium and linear programming. American Economic Review 42 (3), 283-303.

Sauquet, A., Caurla, S., Lecocq, F., Delacote, P., Barkaoui, A., S., G., 2011. Estimating armington elasticities for sawnwood and application to the french forest sector model. Resource and Energy Economics 33(4), 771-781.

Schmidt, M., 2008. The sankey diagram in energy and material flow management. Journal of Industrial Ecology 2, 173-185.

Schwab, O., Zoboli, O., Rechberger, H., 2016. A data characterization framework for material flow analysis. Journal of Industrial Ecolog 21(1), 16-25.

Strutt, A., Turner, J., Haack, R., Olson, L., 2013. Evaluating the impacts of an international phytosanitary standard for wood packaging material: Global and united states trade implications. Forest Policy and Economics 27, 54-64.

UNECE, FAO, 2010. Forest product conversion factors for the unece region. Tech. rep., Geneva timber and forest discussion paper 49

Van Kooten, G., Johnston, C., 2014. Global impacts of russian log export restrictions and the canada-u.s. lumber dispute: modeling trade in logs and lumber. Forest Policy and Economics 39, 54-66. 
Weimar, H., 2009. Der holzfluss in der bundesrepublik deutschland 2009. Tech. rep., Methode und Ergebnis der Modellierung des Stoffflusses von Holz. Johan Heinrich von Thunen - Institut fur Forst- und Holzwirtschaft, Arbeitsbericht. 


\section{Supplementary material}

\section{The Wood fiber unit}

\section{Definitions and abbreviations}

$M$ : mass,

$V:$ volume,

$\mu$ : volumicmass,

$p:$ product,

$w:$ water,

$o:$ other components,

$\tau:$ moisture rate,

$$
\tau=\frac{M_{p}-M_{\tau=0 \%}}{M_{\tau=0 \%}}=\frac{M_{w}}{M_{\tau=0 \%}}
$$

$\tau_{\text {saturation }} \approx 30 \%$. Water can be present in wood in two forms: water in wood fibers and free water. Free water appears above the saturation point and has no impact on the volume. Below the saturation point, wood fibers start to lose water and the volume decreases.

$w f:$ wood fiber at the saturation point

The product is made of a single wood specie and no other components

$$
\begin{aligned}
M_{w f} & =M_{p}+M_{w \text { (evaporated) }} \\
& =M_{\tau=0 \%}+M_{w \text { (product) }}+M_{w \text { (evaporated })} \\
& =M_{\tau=0 \%}+M_{w \text { (saturation) }} \\
& =M_{\tau=0 \%}+M_{\tau=0 \%} \tau_{\text {saturation }} \\
& =M_{\tau=0 \%}\left(1+\tau_{\text {saturation }}\right) \\
& =M_{p} \frac{1+\tau_{\text {saturation }}}{1+\tau_{p}}
\end{aligned}
$$

then

$$
V_{w f}=\frac{M_{w f}}{\mu_{\text {saturation }}}=\frac{M_{p}}{\mu_{\text {saturation }}} \frac{1+\tau_{\text {saturation }}}{1+\tau_{p}}
$$

Note that if $\tau_{p}=\tau_{\text {saturation }}$ (which is the default assumption when no other information is available), then $V_{w f}=V_{p}$. In the model, this is for instance the case for the production of sawnwood.

Furthermore, given a coefficient of retraction $f\left(\tau_{p}\right)$, defined by $V_{p}=f\left(\tau_{p}\right) V_{w f}$, we have:

$$
\mu_{\text {saturation }}=\mu_{p} f\left(\tau_{p}\right) \frac{1+\tau_{\text {saturation }}}{1+\tau_{p}}
$$


and:

$$
V_{w f}=\frac{M_{p}}{\mu_{p} f\left(\tau_{p}\right)}=\frac{V_{p}}{f\left(\tau_{p}\right)}
$$

The product is made of a single wood specie and other components

$$
M_{w f}=M_{p}+M_{w(\text { evaporated })}-\sum_{i} M_{o_{i}}
$$

Then:

$$
V_{w f}=\frac{1}{\mu_{\text {saturation }}}\left(M_{p} \frac{1+\tau_{\text {saturation }}}{1+\tau_{p}}-\sum_{i} M_{o_{i}}\right)
$$

The product is made of different wood species and other components

Let $\alpha_{i}$ be the fraction of wood specie $i$ in the product mix. We have:

$$
V_{w f}=\sum_{i} \frac{\alpha_{i}}{\mu_{\text {saturation } i}}\left(M_{p} \frac{1+\tau_{\text {saturation }}}{1+\tau_{p}}-\sum_{j} M_{o_{j}}\right)
$$

Conversion factors used 


\begin{tabular}{|l|l|l|}
\hline Product & Original unit & Conversion factor $\left(\mathrm{m}^{3}(\mathrm{f})\right.$ / original unit) \\
\hline Standing timber & $\mathrm{m}^{3}$ & 1 \\
Lumber & $\mathrm{m}^{3}$ & 1 \\
Roundwood (imported or & Tonnes & softwood: 1.05, hardwood: 1.12, hy- \\
exported) & & pothesis: greenwood density \\
Pulpwood & $\mathrm{m}^{3}$ & 1 \\
Fire wood & $\mathrm{m}^{3}$ & 1 \\
Forest wood chips & $\mathrm{m}^{3}$ & 1 \\
Ties & $\mathrm{m}^{3}$ & 1 \\
Staves & $\mathrm{m}^{3}$ & 1 \\
Sawnwood & $\mathrm{m}^{3}$ & 1 \\
Sawnwood (imported or ex- & Tonnes & softwood: 1.36, hardwood: 1.75, hy- \\
ported) & & pothesis: $15 \%$ moisture \\
Sawmill residues & Tonnes & 1.1 \\
Sawmill woodchips & Tonnes & 1.1 \\
Veneer & $\mathrm{m}^{3}$ & 1 \\
Particle board* & $\mathrm{m}^{3}$ & 1.25 \\
Fibreboard* & $\mathrm{m}^{3}$ & 1.47 \\
MDF board* & $\mathrm{m}^{3}$ & 1.39 \\
Plywood* & $\mathrm{m}^{3}$ & 0.96 \\
Wood floor & $\mathrm{m}^{2}$ & 0.015 \\
Pallets and wood packaging & Tonnes & 1.1 \\
Mechanical paper pulp* & Tonnes & 2.22 \\
Chemical paper pulp* & Tonnes & 2.13 \\
Old papers* & Tonnes & 1.54 \\
Paper, cardboards* & Tonnes & 1.54 \\
Wood wastes & Tonnes & 1.1 \\
\hline
\end{tabular}

Table 6: Conversion factors (to wood fiber equivalent $\left.\left(\mathrm{m}^{3}(\mathrm{f})\right)\right)$ used in the study. Products marked with a $*$ are taken from Weimar (2011), the others are provided by the authors. 


\section{FFSM Calibration coefficients}

\begin{tabular}{|l|l|l|l|l|l|l|}
\hline & fw & hsw & ssw & pw & panels & pulp \\
\hline HRW & & 2.18 & & 1.34 & & \\
\hline SRW & & & 2.02 & 1.34 & & \\
\hline IW & 1 & & & & 1 & 1.67 \\
\hline
\end{tabular}

Table 7: Input-output coefficients used in the Leontief function of FFSM, calibrated using MFA results. These coefficients represent the quantity of raw products (HRW, SRW, IW) required to produce one unit of transformed product (fw, hsw, ssw, pw, panels, pulp). Some industries are assumed to produce no waste residues (fw, panels) according to MFA. Plywood is assumed to be made of either HRW or SRW.

\section{Equations of the Material flow analysis}

This formalism was already presented in Courtonne et al. (2015). The optimization function has however been adapted for the present study as we explain below.

As shown above, the supply table comprises the supply matrix $V$ and the imports vector $I$ whereas the use table comprises the use matrix $U$, the exports vector $E$ and the (final) consumption vector $C$. For instance $U_{i j}$ refers to the quantity of product $i$ that is used by sector $j$ and $C_{i}$ refers to the quantity of product $i$ that is consumed by end-users on the territory. These tables are subject to constraints (we use hats above letters to refer to data resulting from the reconciliation process, original data are represented without a hat):

- Constraint 1: mass conservation of each product (note that stocks are neglected because we are working on a five-years average):

$$
\sum_{j} \hat{V}_{i j}+\hat{I}_{i}=\sum_{j} \hat{U}_{i j}+\hat{E}_{i}+\hat{C}_{i} \quad i=1 . . n
$$

- Constraint 2: mass conservation in every transforming industry:

$$
\sum_{i} \hat{V}_{i j}=\sum_{i} \hat{U}_{i j} \quad j=1 . . m \quad \text { and } \mathrm{j} \text { is a transforming sector }
$$

- Constraint 3: Technical conversion factors between products (e.g. rate of sawmill residues),

- Constraint 4: All flows have positive values,

- Constraint 5: Matrices $\hat{V}$ and $\hat{U}$ are sparse (mostly empty), for instance the wood panel industry cannot produce nor consume sawnwood.

Note that constraint 1 does not apply to standing wood in forest to allow the increase of final stock in forest and natural mortality.

Our goal is to minimize the discrepancy between original data and estimated/output data while respecting the constraints. This problem can be expressed in many ways depending on the expression of the distance between original and final data. We first used a classic weighted least square optimization: 


$$
\begin{aligned}
\min ( & \sum_{i} \sum_{j} \frac{\left(\hat{V}_{i j}-V_{i j}\right)^{2}}{\sigma_{V i j}^{2}}+\sum_{i} \sum_{j} \frac{\left(\hat{U}_{i j}-U_{i j}\right)^{2}}{\sigma_{U i j}^{2}}+\sum_{i} \frac{\left(\hat{I}_{i}-I_{i}\right)^{2}}{\sigma_{I i}^{2}}+\sum_{i} \frac{\left(\hat{E}_{i}-E_{i}\right)^{2}}{\sigma_{E i}^{2}} \\
& \left.+\sum_{i} \frac{\left(\hat{C}_{i}-C_{i}\right)^{2}}{\sigma_{C i}^{2}}\right)
\end{aligned}
$$

subject to the set of constraints 1 to 5

In equation 7, $\sigma$ refers to the standard deviation of the data. They make it possible to treat data sources differently depending on the assumed (or possibly measured, or constrained) uncertainties. We however changed the distance used for minimization we because we found weighted least squares could lead to extreme allocations in specific cases. The minimization implemented is the following:

$$
\begin{aligned}
\min & \left(\sum_{i} \sum_{j} \frac{\left(\hat{V}_{i j}-V_{i j}\right)^{2}}{\sigma_{V i j}}+\sum_{i} \sum_{j} \frac{\left(\hat{U}_{i j}-U_{i j}\right)^{2}}{\sigma_{U i j}}+\sum_{i} \frac{\left(\hat{I}_{i}-I_{i}\right)^{2}}{\sigma_{I i}}+\sum_{i} \frac{\left(\hat{E}_{i}-E_{i}\right)^{2}}{\sigma_{E i}}\right. \\
& \left.+\sum_{i} \frac{\left(\hat{C}_{i}-C_{i}\right)^{2}}{\sigma_{C i}}\right) \\
& \text { subject to the set of constraints } 1 \text { to } 5
\end{aligned}
$$

We divide each term by $\sigma$ instead of dividing it by $\sigma^{2}$. We consider this distance a good balance between penalizing absolute and relative differences. Testing the impact of different plausible distances on results is part of our next research leads. 


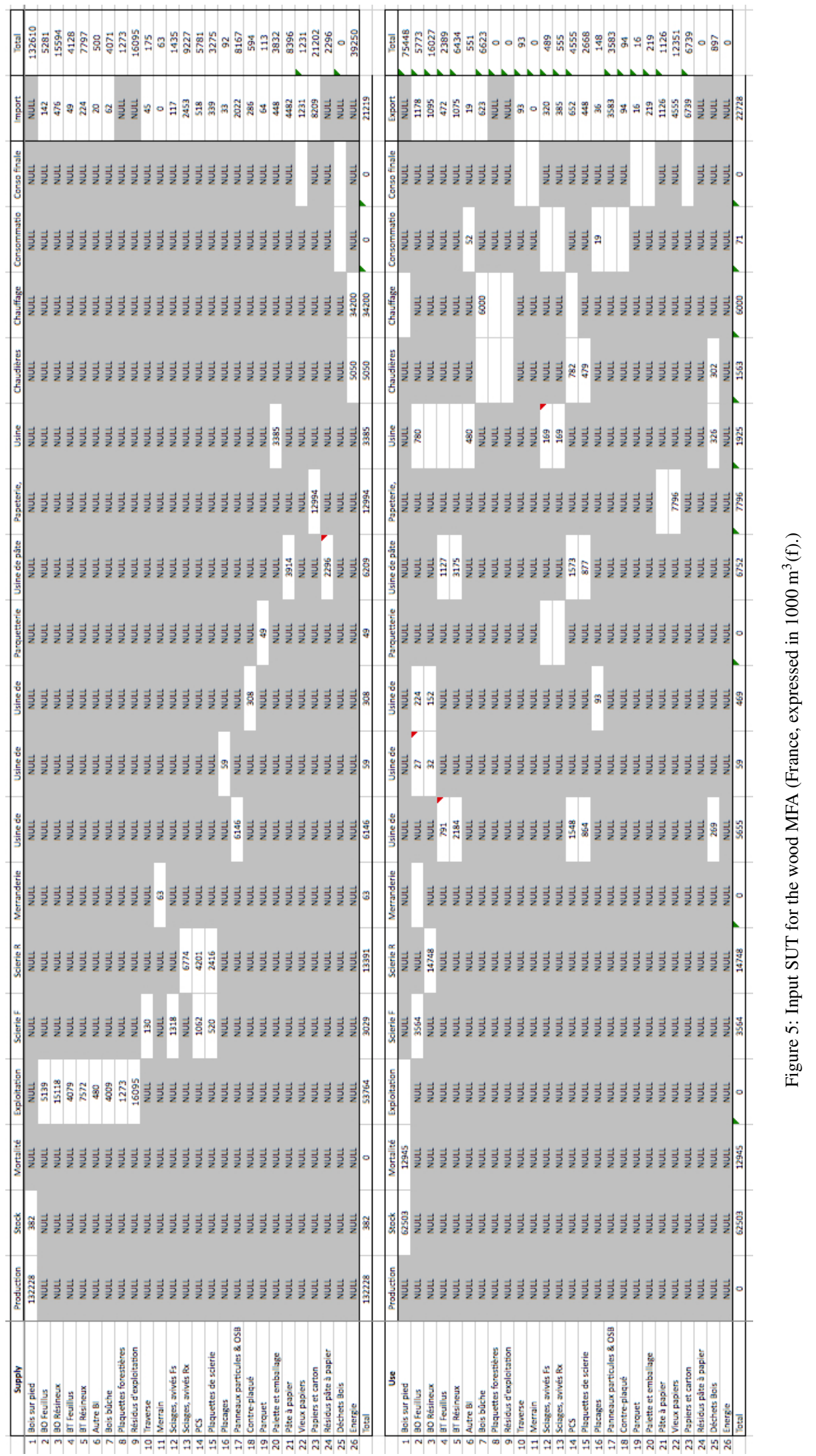




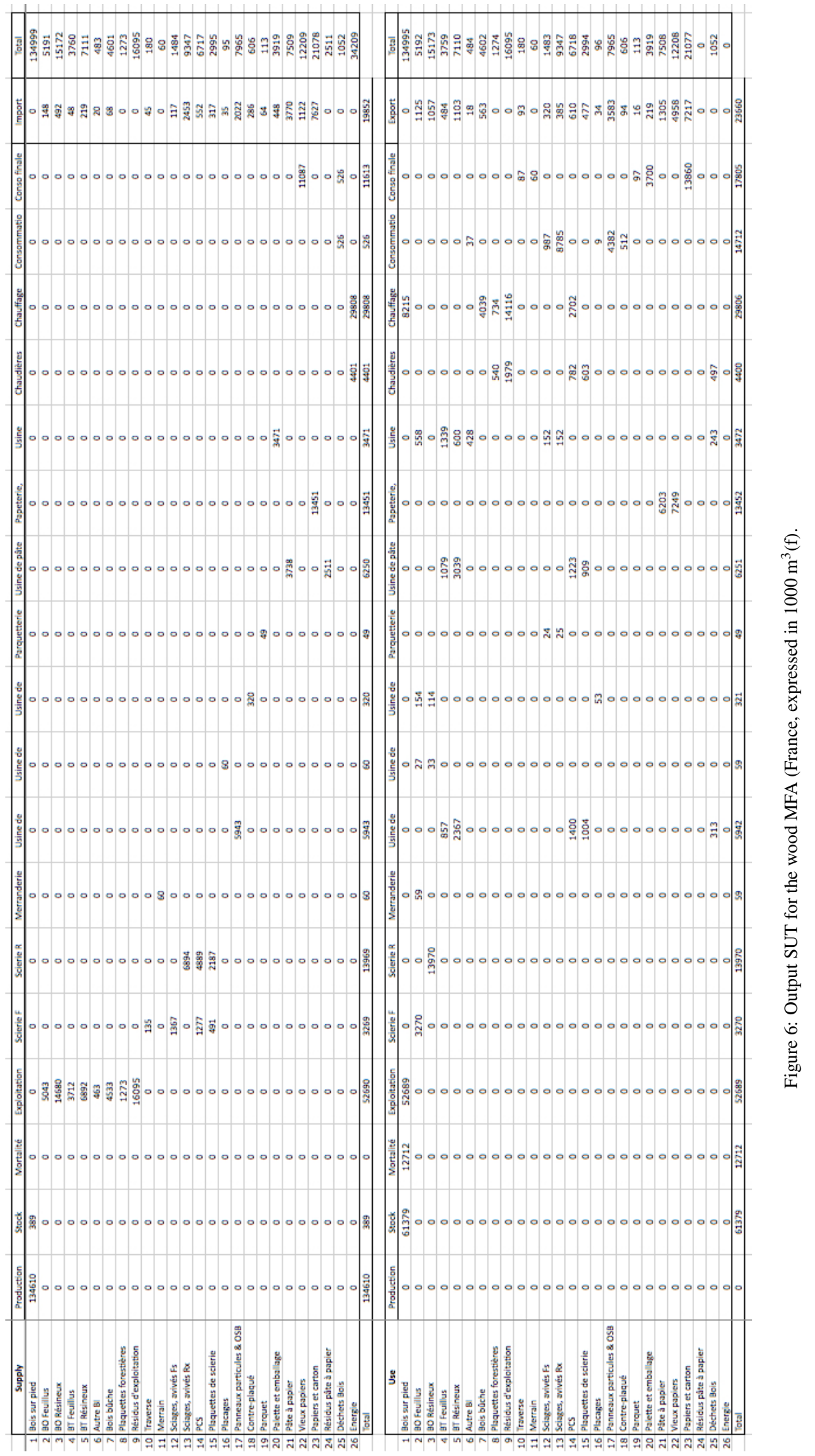



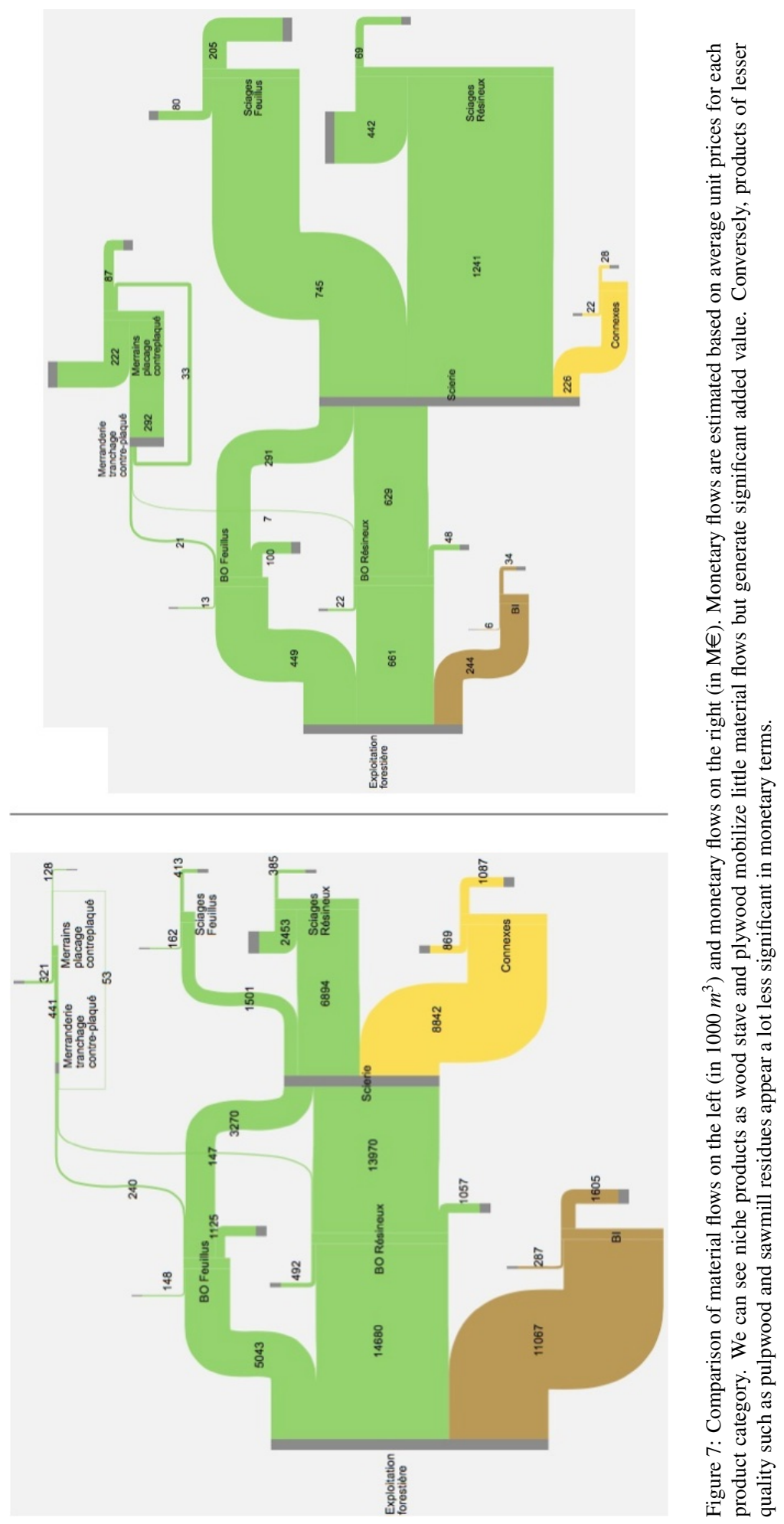


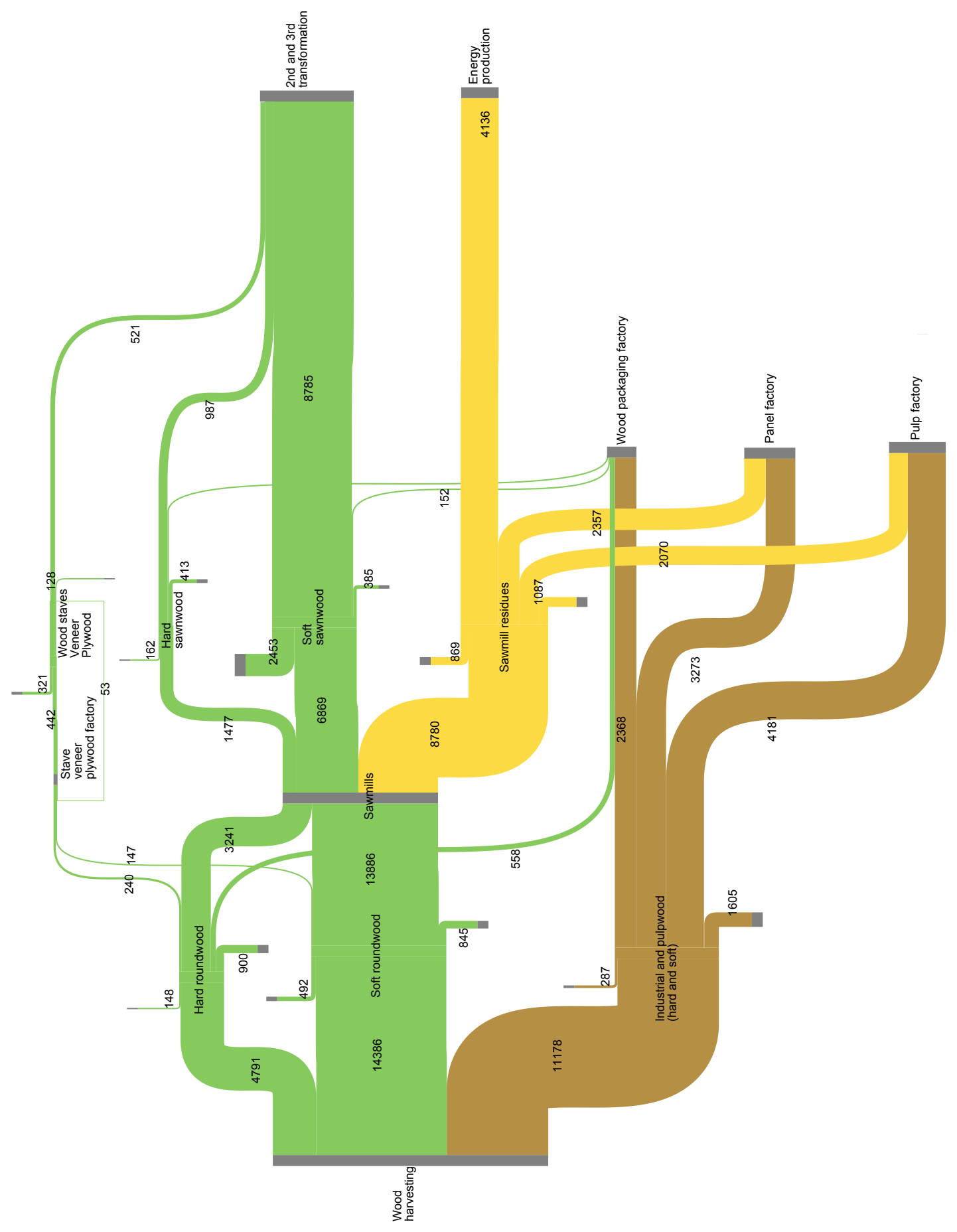

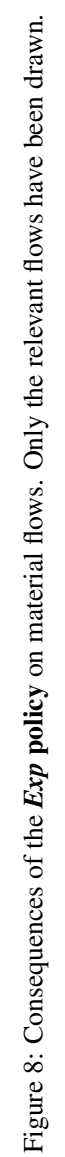




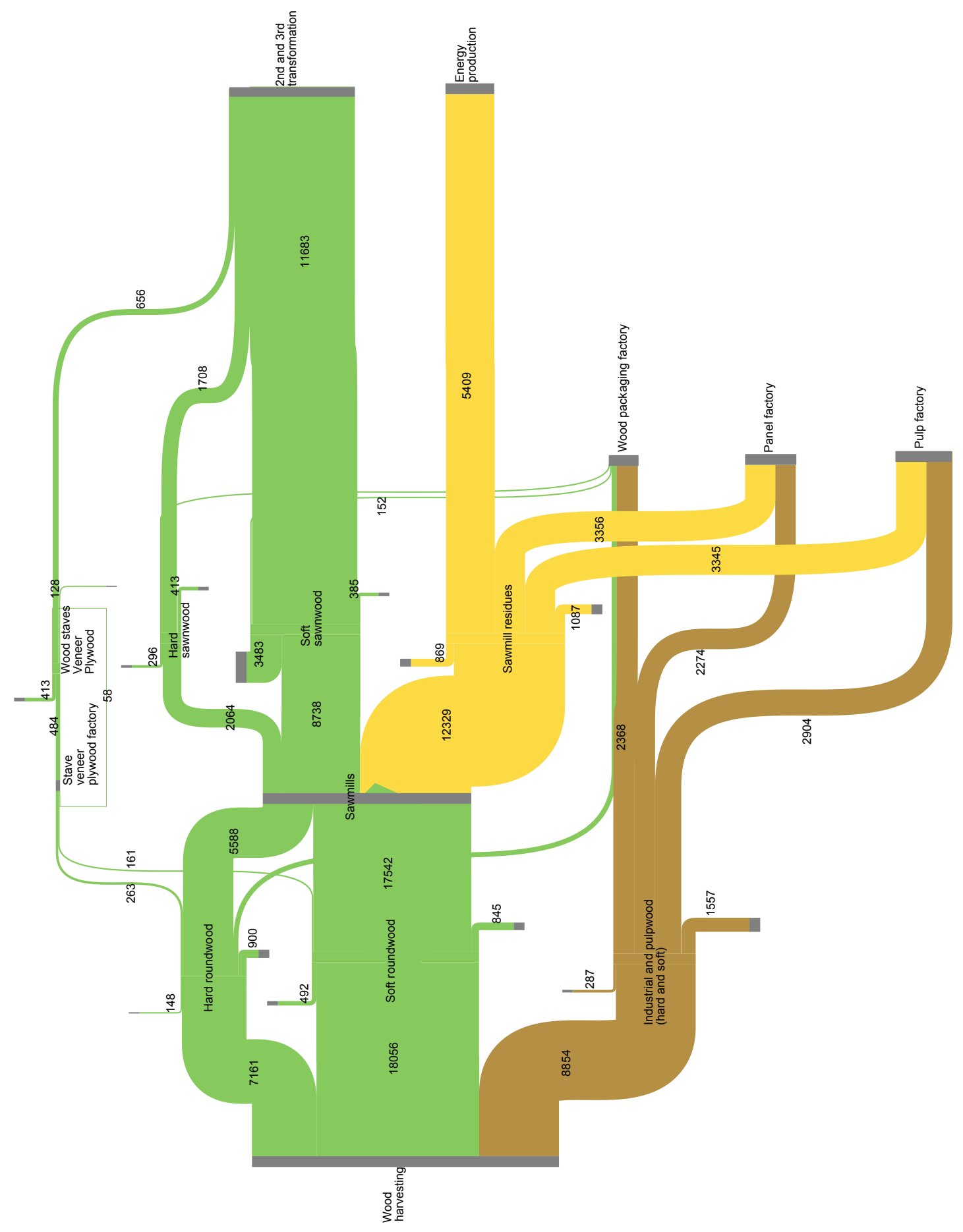

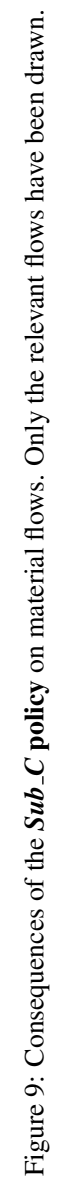




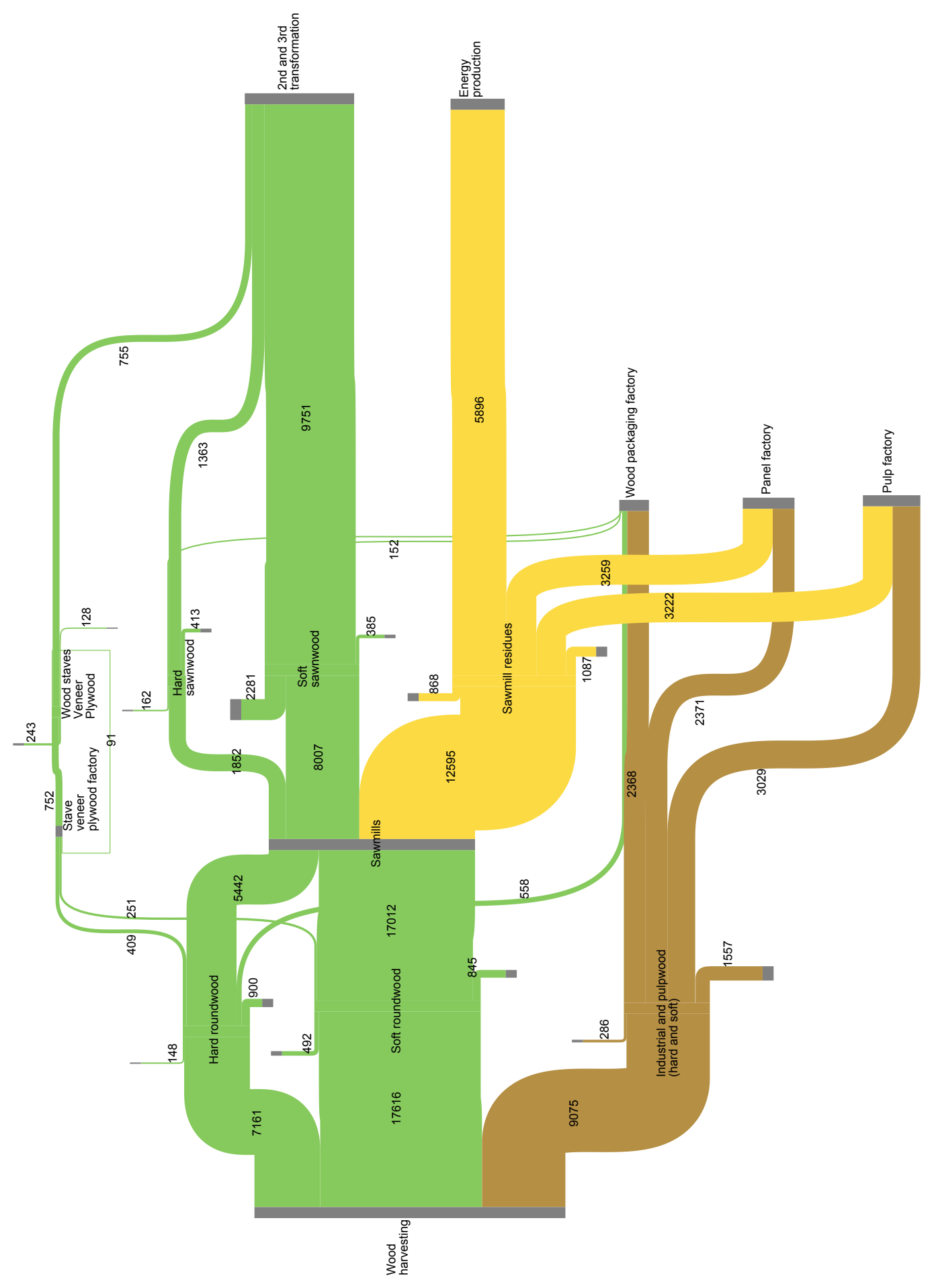

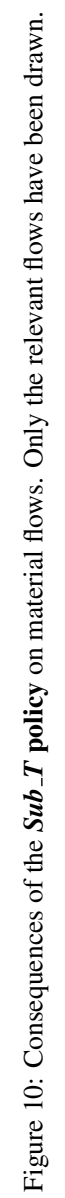




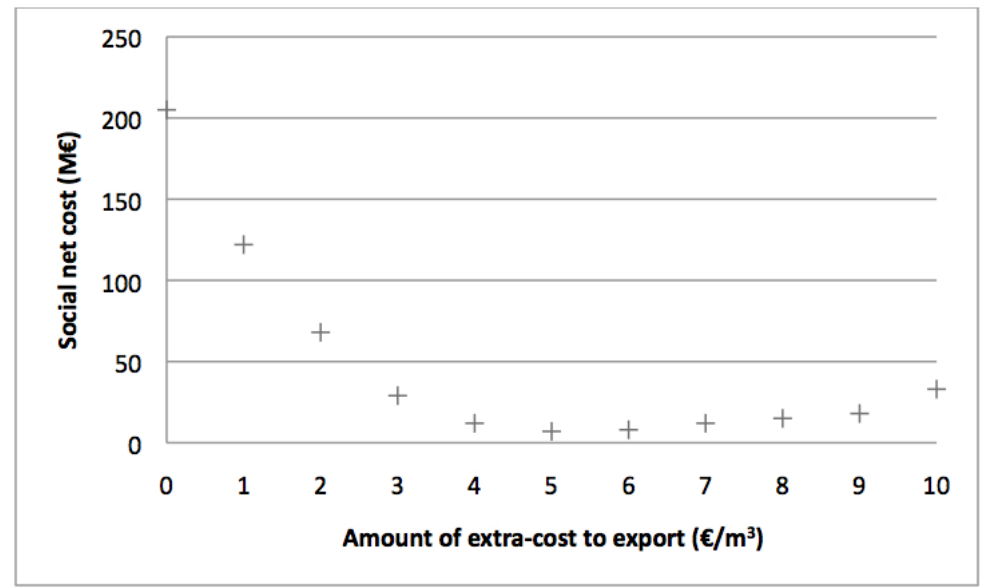

Figure 11: Evolution of social cost depending on the Exp - Sub_T policy mix. The graph represents social costs for 11 combinations that all lead to the same decrease in export of $20 \%$. Only Exp value is presented on the X-basis, the level of the Sub_T is then chosen by a trial and error process. Results shows a U-shaped curve with a minimum for $E x p=5 € / \mathrm{m} 3$ and $S u b_{-} T=80 \%$. The net social cost is then $7 \mathrm{M} €$, which is smaller than the Exp policy alone and which makes this combination potentially interesting from a cost-efficiency perspective. 